\title{
EUROPEAN JEWRY AND THE FIRST CRUSADE
}





\section{EUROPEAN JEWRY AND THE FIRST CRUSADE}

Robert Chazan 
University of California Press

Berkeley and Los Angeles, California

University of California Press, Ltd.

London, England

Copyright $(\mathcal{C} 1987$ by The Regents of the University of California

Library of Congress Cataloging-in-Publication Data

Chazan, Robert.

European Jewry and the First Crusade.

Bibliography: $p$.

Includes index.

1. Jews-Germany-History-1096-1147. 2. JewsGermany-Persecutions. 3. Crusades-First, 1096-1099Jews-Germany. 4. Germany-Ethnic relations. I. Title.

DS135.G31C45 $1987 \quad 943^{\prime} .004924 \quad 86-6938$

ISBN 0-520-05566-7 (alk. paper)

Printed in the United States of America

123456789 